\title{
THE IMPACT OF SELECTED ECONOMIC DETERMINANTS ON INCOME INEQUALITY: THE CASE OF THE EU
}

\author{
İmre ERSOY* \\ Bilgehan BAYKAL ${ }^{* *}$
}

\section{Abstract}

Income inequality particularly in advanced countries is one of the biggest problems of our time. Studies also state that the inequality in advanced countries is mainly associated with the recent crisis. This is why the EU 2020 Strategy aims at achieving an inclusive and sustainable growth in the EU. The paper investigates the determinants of income inequality in the EU in terms of GDP growth, private sector debt, social benefits, unemployment and tax from low wages. The concerned indicators like low GDP growth as well as high private sector debt, high social benefits, high unemployment and high tax from low wages in terms of austerity measures have been the characteristics of some of the EU countries due mainly to the crisis. To this end, panel data of $27 \mathrm{EU}$ countries for the period of 2004-2014 are employed, where Gini coefficient is the dependent variable. Our analysis points out to social benefits and unemployment as the economic determinants of income inequality in the EU between 2004 and 2014. Income inequality increases as unemployment increases and as social benefits decreases. Yet GDP growth, private sector debt and tax from low wages do not have an impact on income inequality in the EU member states.

Keywords: income inequality, EU, panel data models

\footnotetext{
*Associate Prof. Dr., Marmara University, EU Institute, Department of EU Economics, e-mail: iersoy@marmara.edu.tr

** Dr., e-mail: bilgehanbaykal@gmail.com
} 


\section{SEÇILII EKONOMIK FAKTÖRLERIN GELIR EŞITSSIZLIĞí ÜZERINDEKI ETKISII: AB ÖRNEĞí}

\section{$\ddot{\boldsymbol{O}} z$}

Özellikle gelişmiş ülkelerdeki gelir adaletsizliği zamanımızın en büyük problemlerinden biridir. Çalışmalar gelişmiş ülkelerdeki eşitsizliğin krizlerden de kaynaklandığını göstermektedir.Bu nedenle AB 2020 stratejisi AB'de kapsayıcı ve sürdürülebilir bir büyümeye ulaşmayı hedeflemektedir. Bu çalışma AB'de gelir adaletsizliğini, GSMH büyümesi, özel sektör borcu, sosyal yardımlar, işsizlik ve düşük ücretliler üzerinden alınan vergiler kapsamında incelemektedir. Düşük büyüme, yüksek özel sektör borcu, yüksek sosyal yardımlar, yüksek işsizlik ve kemer sıkma politikaları kapsamında düşük ücretlilerden yüksek vergi alınması gibi söz konusu göstergeler özellikle $k$ riz nedeniyle bir çok $A B$ ülkesinin özelliği haline gelmiştir. Bu nedenle 27 AB ülkesinin 2004-2014 yılları için panel datası oluşturulmuş ve Gini katsayısı da bağımlı değişken olarak kullanılmıştır. Çalışmanın sonuçları sosyal yardımlar ve işsizliğin 2004-2014 yılları için AB'de gelir adaletsizliğinin ekonomik göstergeleri olduğuna işaret etmektedir. İssizlik arttıkça ve sosyal yardımlar azaldıkça gelir adaletsizliği artmaktadır. Ancak GSMH büyümesi, özel sektör borcu ve düşük ücretlilerin vergilerindeki artış $A B$ ülkelerinde gelir adaletsizliği üzerinde etki yaratmamaktadır.

Anahtar Kelimeler: Gelir adaletsizliği, AB, Panel data

\section{Introduction}

Income inequality is widening globally and this is especially the case in advanced economies, as well as in most emerging and developing countries (IMF, 2105). Yet, excessive inequality is downplayed for too long now (Atkinson, 2013). As can be seen from figure 1 below, inequality has risen to a great extent since 1990 in most of the developed countries. 


\section{Figure 1: Change in Net Gini Index, 1990-2012}

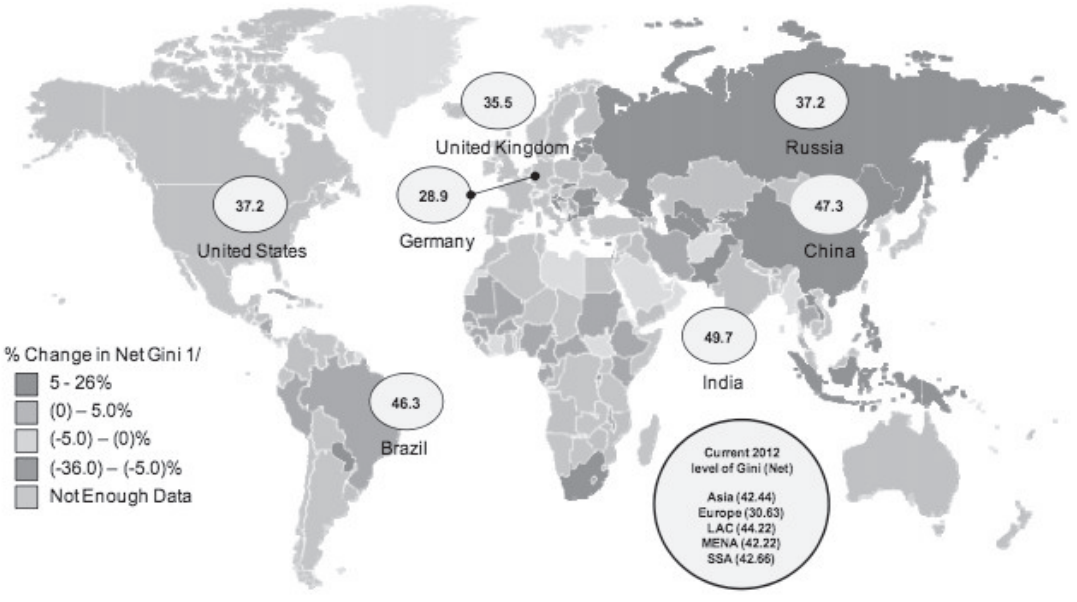

Source: IMF, 2015

When one looks closer to the case of the European Union (EU), it is possible to see that inequality has risen largely since mid-1980s and the reason is not solely the EU enlargement since inequality has also increased within the eight core European countries (Bonesmo, 2012), and inequality has also increased in Eastern Europe (IMF,2015). Between 1990 and 2010, Gini index has increased in all of European countries, advanced and emerging (IMF, 2014). For this, Europe 2020 strategy aims to overcome the effects of the crisis which caused $10 \%$ of active population to be unemployed, and turn EU into a "smart, sustainable and inclusive economy, delivering high levels of employment, productivity and social cohesion" (EC,2010).

Within this context, several indicators may be considered as important determinants of inequality in the EU. The first determinant to be investigated is growth since increase in income inequality is associated with low growth in the EU. Another indicator, which deserves a closer look in the examination of the reasons of inequality, is the private sector debt, which is seen as culprit of the crisis at least in (Greece, Italy, Ireland, Portugal and Spain) GIIPS countries. Austerity measures after the Eurozone crisis encompass taxes (even from low wages) and the inequality and tax relationship deserves a closer look at least to understand whether if austerity measures increased income inequality in the EU.

On the other hand, in the context of Europe 2020 social cohesion and the increase in employment are the main targets for EU to reach its goals by 2020 . Social benefits include items such as allowances for sickness, maternity, care of 
dependents and family, whereas employment is handled as a separate economic determinant. Within this framework, social benefits and employment are the last two determinants to be investigated for their associationship with income inequality.

The aim of this study is to reveal the determinants which affect the income inequality in the EU. We are investigating the relationship between the GINI coefficient and GDP growth, private sector debt, tax rate on the low wage earners, unemployment and social benefits in the EU countries.

The rest of the paper unfolds as follows: Section 2 reviews the literature. Section 3 portraits data and methodology. Section 4 depicts finding and discussions. Section 5 finally concludes.

\section{Literature Review}

There are quite a number of studies analysing the impact of certain determinants on income inequality for the world economies. To cite only a few, IMF (2013) examines if rising inequality is associated with technology or trade and financial globalization. The study finds out that the impact of technological progress is higher on income inequality when compared with globalization. Yet financial globalization is found to affect income inequality positively and trade globalization negatively. IMF(2015) concentrates on poor and middle class and uses trade integration, financial globalization, technology, financial market development, skill premium, education, labour market flexibility, female mortality and government spending to explain income inequality in 97 countries. The empirical analysis shows that certain indicators have higher impact on income inequality; yet the drivers of inequality differ amongst countries.

The low growth in the EU is associated with the increase in income inequality ${ }^{1}$. The literature on growth and inequality dates back to Kuznets (1955). His theory envisages an inverted U-shaped relationship between income levels and income inequality, which means inequality increases in low-income countries and then decreases in high-income countries. Yet, i.e. Deiniger, K. and Squire, L. (1997), find that growth does not negatively affect income distribution. A recent study finds for US that higher growth and future growth increases income inequality (Rubin and Segal, 2015). Yet another study (OECD, 2014) suggests that income inequality affects growth negatively. Hence, the impact of growth on income inequality needs to be empirically analysed for the case of EU.

\footnotetext{
${ }^{1}$ Income Inequality deals with inter-personal distribution of income across the population at a point in time (IMF, 2014).
} 
Private sector debt, which is one of the important culprits of the Euro-zone crisis of at least the GIIPS countries (excluding Greece, which had much higher government debt than private sector debt) may be analysed for its effect on income inequality. For the relationship between debt and inequality, Iacoviello (2005) finds that the rise in within group income inequality explains the private sector debt. On the other hand, Cournede et. al (2015) uncover that in OECD countries financial expansion, that is more of private sector borrowing causes more of income inequality because it is mainly the high income people who can borrow more and hence profit more from the various investment opportunities.

Another indicator, which needs a closer look, is the tax increase even from low wages in the context of austerity measures applied in the Eurozone countries. The econometric analysis indicates that the higher the income taxes, the more reduced the inequality, but the impact of corporate income tax reduction on inequality is mixed and consumption taxes are less effective in reducing inequality (IMF,2014).

In addition to income taxes, social transfers are found to decrease income inequality by a third in advanced countries, where social transfers encompass mainly pensions and family benefits (Clements, 2014). Employment, which may be considered within the context of social transfers, is handled separately in this paper. Sheng (2011) finds for the USA that unemployment and income inequality are positively correlated. According to OECD (2012), labour compensation in terms of wages, salaries and benefits have declined to the levels of $61.7 \%$ in 2000 when compared with $66.1 \%$ in 1990 s. The increasing income inequality and the decline of labour compensation also gives a clue about the negative relationship between social transfers and income inequality.

The literature review shows us that the impact of growth on income inequality is mixed. In terms of the impact of private credit, an econometric inquiry for OECD countries finds a positive relationship with income inequality. Hence, the case of EU should be analysed to see if the results of the econometric investigation produces the same results for the EU. The relationship between tax increase in the context of austerity measures and income inequality shows that in terms of income tax there is a positive relationship with income inequality, the case of corporate tax gives mixed results and consumption taxes are less effective in reducing inequality. Hence, the relationship between taxes and income inequality necessitates a closer look for the case of EU. On the other hand, studies regarding OECD and US show a negative relationship between social transfers and income inequality and a negative relationship between unemployment and income inequality. Hence, even though there are some studies about the impact of certain indicators on income inequality, the lack of empirical analysis on the impact of these 
determinants on income inequality for the EU renders the empirical analysis for the case of EU indispensable.

\section{Data\& Methodology}

\subsection{Data}

We constructed a panel equation for the EU countries using GINI coefficient(GINI) ${ }^{2}$ as the dependent variable and the explanatory variables which are GDP growth rate(gdpgr $)^{3}$, private sector $\operatorname{debt}(\mathrm{pdebt})^{4}$, unemployment(unemployment) ${ }^{5}$, tax from the low wage earners $(\operatorname{tax})^{6}$ and social benefits (socben $)^{7}$. All data is taken from Eurostat.

2 The Gini coefficient is defined as the relationship of cumulative shares of the population arranged according to the level of equialised disposable income, to the cumulative share of the equialised total disposable income received by them. (Eurostat, 2016)

3 The calculation of the annual growth rate of GDP volume is intended to allow comparisons of the dynamics of economic development both over time and between economies of different sizes. For measuring the growth rate of GDP in terms of volumes, the GDP at current prices are valued in the prices of the previous year and the computed volume changes are imposed on the level of a reference year; this is called a chain-linked series. Accordingly, price movements will not inflate the growth rate. (Eurostat, 2016)

${ }^{4}$ The private sector debt is the stock of liabilities held by the sectors Non-Financial corporations (S.11) and Households and Non-Profit institutions serving households (S.14_S.15). The instruments that are taken into account to compile private sector debt are Debt securities (F.3) and Loans (F.4). Data are presented in consolidated terms, i.e. does not take into account transactions within the same sector, and expressed in \% of GDP and million of national currency. Definitions regarding sectors and instruments are based on the ESA 2010. (Eurostat, 2016)

${ }^{5}$ The unemployment rate is the number of unemployed persons as a percentage of the labour force based on International Labour Office (ILO) definition. The labour force is the total number of people employed and unemployed. Unemployed persons comprise persons aged 15 to 74 who: - are without work during the reference week; - are available to start work within the next two weeks; - and have been actively seeking work in the past four weeks or had already found a job to start within the next three months. (Eurostat, 2016)

${ }^{6}$ The unemployment trap measures what percentage of the gross earnings (after moving into employment) is 'taxed away' by the combined effects of the withdrawal of benefits and higher tax and social security contributions. (Eurostat, 2016)

${ }^{7}$ Social benefits (other than social transfers in kind) refer to the benefits paid by government (ESA 2010 code D.62) which are transfers to households, in cash or in kind, intended to relieve them from financial burden of a number of risks or needs (by convention: sickness, invalidity, disability, occupational accident or disease, old age, survivors, maternity, family, promotion of employment, unemployment, housing, 


\subsection{Model}

In panel data form, the model can be written as follows:

$$
\begin{aligned}
& \text { GINI }=\lambda_{i} d_{t}+\beta_{1 i} \text { gdpgr }_{\boldsymbol{t}}+\beta_{2 i} \text { pdebt }_{t}+\beta_{3 i} \text { unemployment }_{t}+ \\
& \beta_{4 i} \text { tax }_{\boldsymbol{t}}+\beta_{5 i} \text { socben }_{t}+u_{i t}
\end{aligned}
$$

In the above equation, there are 27 EU countries. With annual series from 2004 to 2014 and some missing values are filled with the mean values. ${ }^{8}$

$$
\begin{aligned}
& u_{i t}=\boldsymbol{\theta}_{i} f_{t}+\varepsilon_{i t} \\
& i=1,2, \ldots . N \text { and } \\
& t=1,2, \ldots . T
\end{aligned}
$$

where

$d_{t}$ is observed and $f_{t}$ is unobserved common effects. Cross sectional dependence may be possible for this model, which will be tested.

\subsection{Methodology}

As a first step, we specify our model. Our decision is fixed-effects model as our sample data is not random and it encompasses EU countries.

After the data selection and model specification, we test our assumptions starting with the cross-sectional dependency. Cross-sectional dependency helps us to decide whether we are going to use the first generation or secondgeneration unit root tests.

Based on the assumption that our time series of the dependent and explanatory variables are stationary, we run the F-tests to test the individual and time effects to decide one-way or two-way error component models. Third, we test the heteroscedasticity and auto correlation. Based on the heteroscedasticity and auto-correlation tests, we select the estimation model.

\subsubsection{Cross Sectional Dependency}

After we decide our model, we consider the cross sectional (CD) dependency. Cross sectional dependence is an important issue and should be taken into account both in estimating and testing with panel data models.

education and general neediness), made through collective schemes, or outside such schemes by government units. (Eurostat, 2016)

${ }^{8}$ Missing values for tax; Bulgaria- 2005, 2006, 2007; Cyprus-2008, 2009, 2010, 2011, 2012, 2013, 2014; Romania- 2005, 2006, 2007. Missing values for GINI; Bulgaria2004, 2005, Cyprus-2004; Czech Republic- 2004; Germany-2004; Hungary-2004; Latvia-2004; Lithuania-2004; Malta-2004; Netherlands-2004; Romania -2004, 2005, 2006; Slovakia-2004; Slovenia-2004; United Kingdom-2004. 
The CD test statistic given in Pesaran(2004) follows a standard normal distribution and it is able to handle balanced and unbalanced panels.

The CD test by Friedman(1937) uses Friedman's chi-square distributed statistic. For unbalanced panels Friedman's test uses only the observations available for all cross-sectional units.

\subsubsection{Unit Root Tests}

Because there is no cross sectional dependency between the time series, we can apply first generation unit root tests. Im-Pesaran-Shin (IPS) (2003) test has the null hypothesis of all panels have unit root. IPS test allows heterogeneous coefficients.

$H 0: \rho_{i}=0 \forall_{i}$

Alternative hypothesis allows some of the individuals to have unit roots.

$H 1:\left\{\begin{array}{c}\rho_{i}<0 \text { for } i=1,2, \ldots \ldots, N_{i} \\ \rho_{i}=0 \text { for } i=N_{i}+1, \ldots \ldots, N\end{array}\right.$

The Im-Pesaran-Shin (IPS) test is not as restrictive as the Levin-Lin-Chu (2002) test, since it allows for heterogeneous coefficients. The null hypothesis is that all individuals follow a unit root process:

\subsubsection{Fixed Effect Tests}

To decide if our panel equation has fixed effects, we run $F$ tests. The null hypothesis for the first test is the absence of the individual and time effects where the null hypothesis for the second and the third tests are absence of individual effects and time effects respectively.

\subsubsection{Heteroskedasticity Tests}

Heteroskedasticity assumption is;

$$
E\left(v_{i t}^{2} \mid X_{i}, Z_{i}, \alpha_{i}\right)=\sigma_{i t}^{2}=\sigma_{v}^{2} h\left(Z_{i t}^{\tau} Y\right)
$$

where

$X_{i}, Z_{i}$ are $T x K$ and Txp matrices which contain the $T$ observations of $X_{i t}$ and $Z_{i t}$ $; \alpha_{i}$ are individual effects and $v_{i}$ is observation specific error term.

$h($.$) is any strictly positive, twice differentiable function such that$

$$
h(0)=1, h^{\prime \prime}(0) \neq 0 \text { and }
$$

$\mathrm{h}(0)=1, \mathrm{~h}^{\prime}(0) \vDash 0$, and $\sigma_{v}^{2}$ is a positive constant.

Juhl Escudero(2014) assumes that "Y=0. $\quad Z_{i t}$ is a vector of $p$ strictly exogeneous variable which may account for heteroskedasticity which can be taken as a subset or all of $X_{i t}$ and $Z_{i t}$ may also include variables that are not 
contained in $X_{i t}$ so long as the assumptions are satisfied"(Juhl\&Escudero, 2004,p:2).

\subsubsection{Auto-Correlation Tests}

Auto correlation is tested by Baltagi-Li (1995). In Baltagi\&Li (1995) model for fixed effects;

$\mathrm{H} 0: \rho=0$ which means there are no serial correlations.

$$
y_{i}=X_{i} \boldsymbol{\beta}+\mu_{i} e_{t}+v_{i}
$$

where

$y_{i}=\left(y_{i 1}, y_{i 2}, \ldots . y_{i t)} \quad X_{i}\right.$ is TxK and $v_{i}$ is Tx 1

$v_{i} \sim N\left(0, \Omega_{\rho}\right)$ where $\Omega_{\rho}=\sigma_{\epsilon}^{2} V_{\rho}$ for the $\mathrm{AR}(1)$ disturbances $)$

\subsubsection{Estimation}

This paper uses fixed-effects linear model with an AR (1) disturbance as there is auto correlation in the panel. Fixed-effects linear model with an AR (1) disturbance is applied in STATA with "xtregar" command. (Baltagi\& Wu, 1999).

Xtregar estimator for fixed-effects model is as follows;

$$
y_{i t}=\alpha+x_{i t} \beta+v_{i}+\epsilon_{i t}
$$

$$
i=1, \ldots N
$$

$t=1, \ldots T_{i}$

$$
\epsilon_{i t}=\rho \epsilon_{i, t-1}+\eta_{i t}
$$

where

$|\rho|<1 ; \eta_{i t}$ is indepedent and identically distributed with mean 0 and variance of $\sigma_{n}^{2}$

Additionally, the model is a fixed effects model where $v_{i}$ is fixed.

If $v_{i}$ is correlated with the covariates of $x_{i t}$ and any $x_{i t}$ that do not vary over $\mathrm{t}$ are collinear with $v_{i}$ and will be dropped from the fixed-effects model. 


\section{Results \& Discussions}

\subsection{Cross Sectional Dependency}

Table 1: Cross Sectional Dependency Test Results

Pesaran's test of cross sectional independence $=1,490, \operatorname{Pr}=0,1363$

Average absolute value of the off-diagonal elements $\quad=0,345$

Friedman's test of cross sectional independence $=16,141, \operatorname{Pr}=0,9327$

Both tests show that there is no cross-sector dependency.

\subsection{Unit Root Tests}

As it may be seen in the Table 2, when we run the IPS test for the GINI, GDP Growth, private sector debt and tax we found out that the null hypothesis is rejected and series are found stationary. Social benefits is found stationary in trend level and unemployment is found stationary with lags.

Table 2: Unit Root Tests

\begin{tabular}{|c|c|c|c|c|}
\hline Explanation & Variable & Z-t-tilde-bar & $\begin{array}{r}\text { Significance } \\
(\mathrm{p} \text { value })\end{array}$ & $\begin{array}{r}\text { Unit Root } \\
\text { Test }\end{array}$ \\
\hline Gini Coeeficient & gini & $-1,61$ & $(0,0537)^{*}$ & - \\
\hline Tax & $\operatorname{tax}$ & $-1,4414$ & $(0,0747)^{*}$ & - \\
\hline Private Sector Debt & pdebt & $-2,6518$ & $(0,0040)^{* * *}$ & - \\
\hline Gdp Growth & gdpgr & $-3,953$ & $(0,0000)^{* * * *}$ & - \\
\hline Unemployment & unemp & $-3,2903$ & $(0,0005)^{* * *}$ & $\operatorname{lags}(1)$ \\
\hline Social Benefits & socben & $-1,8278$ & $(0,0338)^{* *}$ & trend \\
\hline
\end{tabular}

\subsection{Fixed Effect tests}

Our equation contains individual effects where time effects are not significant according to Table 3. 
Table 3: Fixed Effects Test

\begin{tabular}{|rr|}
\hline H01:Absence of Individual and time effects & \\
FH01(36,255) & 56,31 \\
ProbFH01 & 0 \\
& \\
H02:Absence of Individual effects & 76,96 \\
FH02(26,255) & 0 \\
ProbFH02 & \\
& \\
H03:Absence of time effects & 1,21 \\
FH03(10,255) & 0,285 \\
ProbFH03 & 5 \\
\hline
\end{tabular}

4.4 Heteroskadasiticty Test

Table 4: Heteroskadasticity LM test by Juhl-Sosa Escudero (2014)

H0: Homoscedasticity

$\operatorname{chi} 2(10)=9.03$

Prob $>$ chi2 $=0.5295$

Based on the test results, Ho is accepted therefore there is no heteroskadasticity.

4.5 Auto-Correlation Test

Table 5: Serial Correlation test by Baltagi and Li (1995)

H0: Absence of first order serial correlation

LMrho $=\quad 36.18$

ProbLMrho $=0.0000$ 
Based on the test results, Ho is rejected and there is first order serial correlation.

\subsection{Panel results}

The panel results are shown in Table 6. Our regression based on the fixedeffects linear model with an AR (1) disturbance, shows that GINI coefficient has negative relationship with the social benefits and positive relationship with the unemployment.

The equation is as follows;

$$
\text { GINI }=30,9429+0,1298 \text { unemployment }-0,2746 \text { socben }
$$

\section{Table 6: Panel Results}

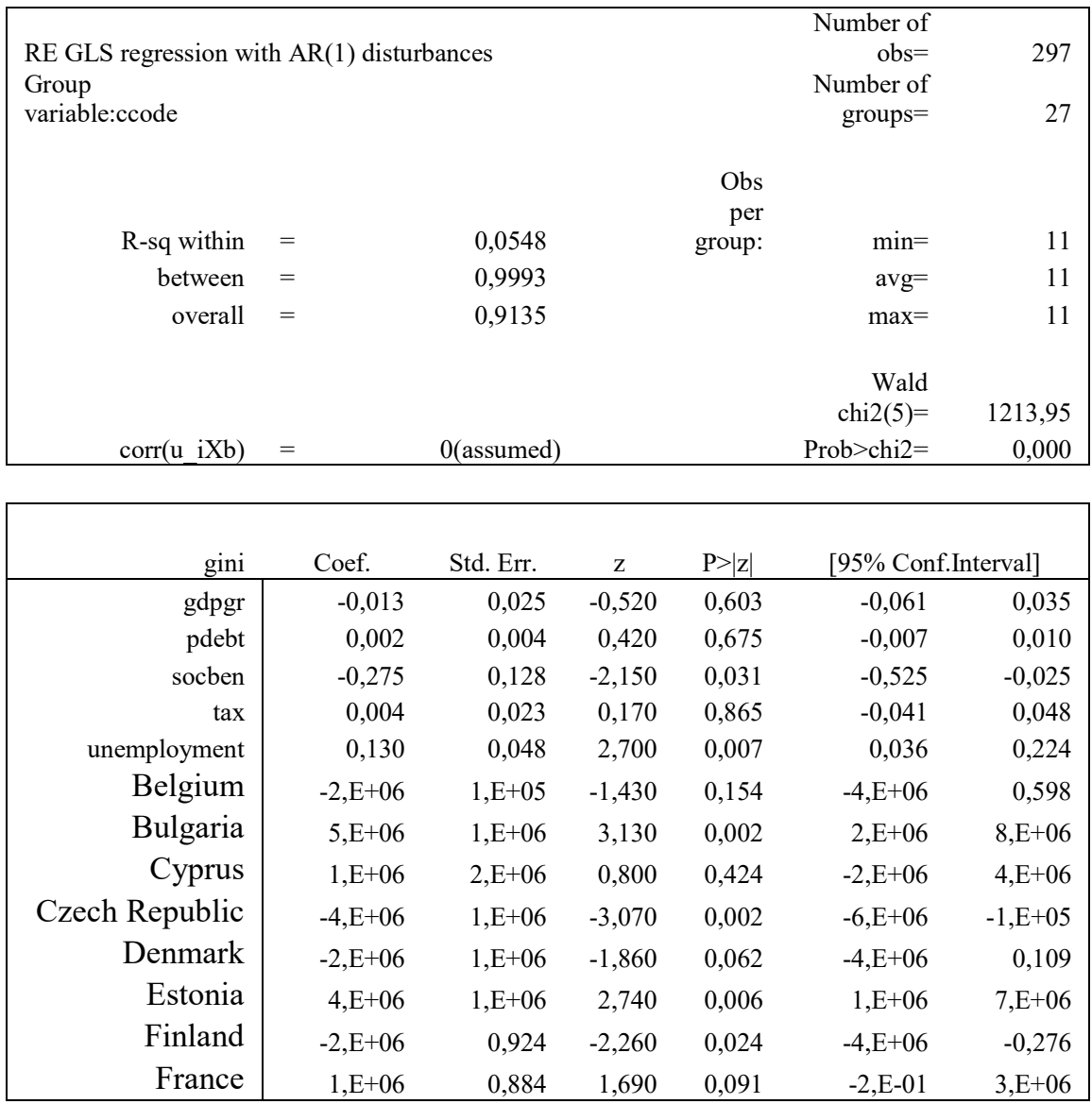




\begin{tabular}{|c|c|c|c|c|c|c|}
\hline Germany & $1, \mathrm{E}+05$ & 0,917 & 1,310 & 0,189 & $-6, \mathrm{E}-01$ & $3, \mathrm{E}+06$ \\
\hline Greece & $5, \mathrm{E}+06$ & $1, \mathrm{E}+06$ & 4,640 & 0,000 & $3, E+06$ & $7, \mathrm{E}+06$ \\
\hline Hungary & $-1, \mathrm{E}+06$ & $1, \mathrm{E}+06$ & $-1,120$ & 0,263 & $-3, E+06$ & 0,897 \\
\hline Ireland & $1, \mathrm{E}+06$ & $2, \mathrm{E}+06$ & 0,660 & 0,506 & $-2, E+06$ & $4, \mathrm{E}+06$ \\
\hline Italy & $5, \mathrm{E}+06$ & 0,882 & 5,250 & 0,000 & $3, \mathrm{E}+06$ & $6, \mathrm{E}+06$ \\
\hline Latvia & $6, \mathrm{E}+06$ & $2, \mathrm{E}+06$ & 3,400 & 0,001 & $3, \mathrm{E}+06$ & $9, \mathrm{E}+06$ \\
\hline Lithuania & $5, \mathrm{E}+06$ & $1, \mathrm{E}+06$ & 3,730 & 0,000 & $2, \mathrm{E}+06$ & $8, \mathrm{E}+06$ \\
\hline Luxembourg & $-3, E-01$ & $1, \mathrm{E}+06$ & $-0,230$ & 0,816 & $-3, E+06$ & $2, \mathrm{E}+06$ \\
\hline Malta & $-1, \mathrm{E}+06$ & $1, \mathrm{E}+06$ & $-1,260$ & 0,209 & $-4, E+06$ & 0,840 \\
\hline Netherlands & $-3, E+06$ & $2, \mathrm{E}+06$ & $-1,970$ & 0,049 & $-6, E+06$ & $-0,013$ \\
\hline Poland & $3, \mathrm{E}+06$ & $1, \mathrm{E}+05$ & 2,550 & 0,011 & 7,E-01 & $5, \mathrm{E}+06$ \\
\hline Portugal & $7, \mathrm{E}+06$ & $1, \mathrm{E}+06$ & 95,000 & 0,000 & $5, \mathrm{E}+06$ & $9, \mathrm{E}+06$ \\
\hline Romania & $5, \mathrm{E}+06$ & $1, \mathrm{E}+05$ & 4,120 & 0,000 & $3, \mathrm{E}+05$ & $8, \mathrm{E}+06$ \\
\hline Slovakia & $-4, E+06$ & $1, \mathrm{E}+06$ & $-3,040$ & 0,002 & $-6, E+06$ & $-1, E+06$ \\
\hline Slovenia & $-4, E+06$ & $1, \mathrm{E}+06$ & $-3,950$ & 0,000 & $-6, E+06$ & $-2, E+06$ \\
\hline Spain & $3, \mathrm{E}+06$ & $2, \mathrm{E}+06$ & 1,980 & 0,048 & 2,E-02 & $6, \mathrm{E}+06$ \\
\hline Sweden & $-4, E+06$ & $1, \mathrm{E}+06$ & $-3,810$ & 0,000 & $-7, E+06$ & $-2, E+06$ \\
\hline UK & 4,E+06 & $1, \mathrm{E}+06$ & 3,520 & 0,000 & $2, \mathrm{E}+06$ & $6, E+06$ \\
\hline cons & 30,943 & 2,334 & 13,260 & 0,000 & 26,369 & 35,517 \\
\hline rho_ar & 0,43434495 & \multicolumn{5}{|c|}{ (estimated autocorrelation coefficient) } \\
\hline sigma_u & 0 & & & & & \\
\hline sigma_e & 1,1291618 & & & & & \\
\hline rho_fov & 0 & \multicolumn{5}{|c|}{$\begin{array}{l}\text { (fraction of variance due to } \\
\left.u \_i\right)\end{array}$} \\
\hline theta & 0 & & & & & \\
\hline
\end{tabular}

\section{Conclusions}

The empirical investigation finds out that as social benefits increase, income inequality decreases. Another finding of the empirical investigation is that as unemployment increases, income inequality increases. The negative relationship of social benefits and the positive relationship between the unemployment and income inequality support the existing literature. Yet, the findings show that gdp growth, private sector debt, and tax from low wages do not have an impact on Gini coefficient. This is important as increasing the GDP of the national economies is pronounced as one of the key solutions to overcome income inequality. Another important finding is that increasing tax from low wages which is one of the key actions in the austerity measures seem to have neither positive nor negative impact on income inequality. Also we found out that the countries who have individual effects which decrease income inequality are Finland, Netherland, Slovakia, Slovenia, Sweden, Czech Rep and Denmark some of which are the Scandinavian countries known for their social 
state policies. The countries who have individual effects which increase income inequality are Bulgaria, France, Greece, Latvia, Lithuania, Poland, Portugal, Romania, Spain, UK and Estonia some of which are the PIIGS countries which were the most affected ones in the Sovereign Debt crisis. The individual country effects on income inequality in the EU should be examined in a separate study. 


\section{References:}

Atkinson, A. B. (2013) "Reducing Income Inequality in Europe", IZA Journal of European Labour Studies, DOI: 10.1186/2193-90 12-2-12.

Baltagi, B. and Li, Q. (1995) "Testing AR (1) against MA (1) disturbances in an error component model”, Journal of Econometrics, 68.

Baltagi, B. H. and Wu, P. X. (1999) "Unequally spaced panel data regressions with AR (1) disturbances”, Econometric Theory, (15): 814-23.

Bonesmo, F. K. (2012) "Income Inequality in the European Union", OECD Economics Department Working Papers, No. 952, OECD Publishing, $<$ http://dx.doi.org/10.1787/5k9bdt47q5zt-en>.

Clements, B., Coady, D., Mooji, R. and Gupta, S. (2014) "Taxing, spending, and inequality-what is to be done?", Voxeu.org.

Cournede, B., Denk, O. and Hoeller, P. (2015) "Finance and Inclusive Growth, OECD Economic Policy Paper”, Number 14.

Deiniger, K. and Squire, L. (1997) "Economic Growth and Income Inequality: Reexamining the Links", Finance and Development.

EC (2010) "Communication from the Commission, Europe 2020: A strategy for smart, sustainable and inclusive growth", Brussels, 3 March 2010.

Eurostat (2016) "EU-SILC survey".

Friedman, M. (1937) "The use of ranks to avoid the assumption of normality implicit in the analysis of variance", Journal of the American Statistical Association, 32, 675-701.

Iacoviello, M. (2005) "Private Debt and Income Inequality: A Business Cycle Analysis", Boston College.

Im, K. S., Pesaran, M. H. and Shin, Y. (2003) "Testing for unit roots in heterogeneous panels", Journal of Econometrics 115: 53-74.

IMF (2013) "Rising Income Inequality: Technology, or Trade and Financial Globalization?” IMF Economic Review, 61 (2).

IMF (2014) "Fiscal Policy and Income Inequality”, IMF Policy Paper.

IMF (2015) Dabla-Norris, E., Kochhar, K., Suphaphiphat, N., Ricka, F., and Tsounta, E. Norris, "Causes and Consequences of Income Inequality: A Global Perspective”, IMF Staff Discussion Note. 
Juhl, T., Sosa-Escudero, W. (2004) "Testing for heteroscedasticity in fixed effects models", Journal of Econometrics.

Kuznets, S. (1955) "Economic Growth and Income Inequality", The American Economic Review, Volume XLV, Number One.

Levin, A., Lin, C. F. and James Chu, C. S. (2002) "Unit root tests in panel data: Asymptotic and finite-sample properties", Journal of Econometrics, 108: 124.

OECD (2012) "Employment Outlook".

OECD, (2014) "Focus on Inequality and Growth".

Pesaran, M. H. (2004) "General diagnostic tests for cross section dependence in panels", Cambridge Working Papers in Economics, 0435, University of Cambridge.

Rubin, A. and Segal, D. (2015) "The effects of economic growth on income inequality in the US", Journal of Macroeconomics, Vol. 45.

Sheng (2011) "Unemployment and Income Inequality: A Puzzling Finding from the US in 1941-2010", <http://ssrn.com/abstract=2020744>. 